\title{
PERSEPSI MAHASISWA D III KEBIDANAN TENTANG PENCEGAHAN ANEMIA DI STIKES KARYA HUSADA SEMARANG
}

\author{
Nichlatur Rohmah ${ }^{1}$, Putri KusumaWardhani ${ }^{2}$ \\ ${ }^{1,2}$ Prodi DIV Bidan Pendidik, Stikes Karya Husada Semarang \\ Email : putri@stikesyahoedsmg.ac.id
}

\begin{abstract}
Abstrak
Latar Belakang: Remaja adalah periode perkembangan selama di mana individu mengalami perubahan dari masa kanak-kanak menuju masa dewasa, terjadi antara usia 13-20 tahun. Istilah adolesens menunjukkan titik di mana reproduksi mungkin dapat terjadi. Perubahan hormonal pubertas mengakibatkan perubahan penampilan pada orang muda, dan perkembangan mental mengakibatkan kemampuan untuk menghipnotis dan berhadapan dengan abstraksi . Tujuan Penelitian: Penelitian ini bertujuan untuk mengeksplorasi secara mendalam tentang gambaran Persepsi Mahasiswa D III Kebidanan Tentang Pencegahan Anemia di STIKES Karya Husada Semarang Tahun 2016. Metode penelitian: Metode penelitian yang digunakan dalam penelitian ini adalah kualitatif, Penelitian ini menggunakan pendekatan fenomenologi, Penelitian ini menggunakan metode purpose sampling,jumlah partisipan dalam penelitian ini tidak ada batasnya tetapi memiliki karakteristik sesuai dengan tujuan penelitian dan kriteria yang sesuai. Hasil Penelitian: Semua mahasiswa di D III Kebidanan STIKES Karya Husada Semarang sudah tahu tentang cara pencegahan anemia dan sudah diterapkan. Semua mahasiswa di D III Kebidanan STIKES Karya Husada Semarang sudah tahu tentang cara meningkatkan pencegahan anemia dan sudah diterapkan dengan cara melakukan diet menu gizi seimbang dan mengkonsumsi buah-buahan yang berguna untuk mencegah terjadinya anemia.
\end{abstract}

Kata Kunci : Persepsi; Mahasiswa; Pencegahan Anemia

\section{PERCEPTION OF THE D III MIDWIFE STUDENTS ABOUT THE PREVENTION OF ANEMIA IN STIKES KARYA HUSADA SEMARANG}

Background: dolescent is a periode of development during which individuals experience the change from childhood to adulthood, occurs between the ages of 13-20 years. Adolesens term indicates the point at which, the reproduction may occur. Hormonal changes lead to changes in the appearance of puberty in young people, and mental development resulted in the ability to hypnotize and dealing with abstractions. Purpose: This study aims to explore in depth about the picture faculty perceptions about D III midwifery Students perception About The prevention of anemia at STIKES Karya Husada Semarang 2015. Method: The method used in this study is a qualitative study using a phenomenological approach, this study used purposive sampling method, number of partisipantsin this study there is no limit but have characteristics consistent with the research objectives and criteria. Result: All students in D III midwifery at STIKES Karya Husada Semarang already know about prevention of anemia, and have applied to students. All students in D III midwifery at STIKES Karya Husada Semarang already know how to prevent anemia and have already applied to students.

Keywords : Student; Perception; Prevention of Anemia 


\section{Pendahuluan}

Remaja putri merupakan salah satu kelompok yang rawan menderita anemia. Prevalensi anemia masih cukup tinggi di Indonesia. Remaja putri mudah terserang anemia karena pada umumnya masyarakat Indonesia lebih banyak menkomsumsi makanan nabati yang kandungan zat besinya sedikit, dibandingkan dengan makanan hewani, sehingga kebutuhan tubuh akan zat besi tidak terpenuhi remaja putri biasanya ingin tampil langsing sehingga membatasi asupan makanan setiap hari manusia kehilangan zat besi 0,6 mg yang diekskresi, khususnya melalui feses (tinja) remaja putri mengalami haid setiap bulan, di mana kehilangan zat besi $\pm 1,3 \mathrm{mg}$ per hari, sehingga kebutuhan zat besi lebih banyak daripada pria (Poltekkes Depkes, 2010).

Anemia pada remaja dapat berdampak pada menurunnya produktivitas kerja atau pun kemampuan akademis di sekolah, Karena tidak adanya gairah belajar dan konsentrasi .terutama pada anak sekolah atau mahasiswa antara lain adalah kesakitan, dan kematian meningkat pertumbuhan fisik, perkembangan otak, motorik, mental dan kecerdasan terhambat daya tangkap belajar menurun, pertumbuhan dan kesegaran fisik menurun serta interaksi sosial kurang. Bahkan anemia dapat menurunkan produktifitas kerja hingga 20\%(Poltekkes Depkes, 2010).

Angka kejadian anemia di Jawa Tengah masih sebesar 30,4\%, Status anemia pada remaja putri berkisar antara $1.016 \%$ (kota Surakarta) dan tertinggi 51,1\% di kabupaten batang. Data Dinas Kesehatan Kota Semarang Tahun 2011 anemia merupakan kasus yang paling banyak ditemukan pada remaja dibandingkan kasus-kasus yang lain. Laporan Program Kesehatan Remaja tahun 2012, jumlah remaja usia 10-19 tahun di Kota Semarang sebanyak 252.133 remaja, dari jumlah tersebut 78.725 (31,22\%) yang mendapat pelayanan oleh petugas kesehatan, sebanyak 2.115 (2,6\%) mengalami anemia. Dari penjelasan diatas peneliti tertarik untuk melakukan penelitian dengan judul Persepsi Mahasiswa D III Kebidanan Tentang Pencegahan Anemia di STIKES Karya Husada Semarang

\section{Tinjauan Teoritis}

Persepsi adalah kemampuan untuk membeda-bedakan, mengelompokan, memfokuskan atau kemampuan untuk mengorganisasikan pengamatan (Sarwono, 2006). Menurut Robins (2008), persepsi dapat didefinisikan sebagai suatu proses yang ditempuh individu-individu 
mengorganisasikan dan menafsirkan kesan-kesan individu agar memberikan makna bagi lingkungan. Menurut Gibson (2000), persepsi adalah proses-proses kognitif yang dipergunakan seseorang untuk menafsirkan dan memahami dunia sekitarnya, mencakup penafsiran objek atau tanda dari sudut pengalaman orang yang bersangkutan.

Perilaku adalah tindakan atau aktifitas dari manusia itu sendiri yang mempunyai bentangan yang sangat luas antara lain berjalan, berbicara, menangis, tertawa, bekerja, kuliah, menulis, membaca dan sebagainya. Dari uraian ini dapat disimpulkan bahwa yang dimaksud perilaku manusia adalah semua kegiatan atau aktifitas manusia, baik yang diamati langsung maupun yang tidak dapat diamati oleh pihak luar (Notoatmodjo, 2010). Perilaku merupakan respon atau reaksi seseorang terhadap stimulus (rangsangan dari luar) Skiner, 1938 dalam Notoatmodjo (2010).

Anemia adalah suatu keadaan dimana kadar hemoglobin dan eritrosit lebih rendah dari normal. Nilai normal hemoglobin pada wanita adalah 12-16 gr\% dengan eritrosit 3,5-4,5 $\mathrm{jt} / \mathrm{mm} 3$. Fungsi hemoglobin dalam darah adalah mengikat oksigen di paru-paru dan melepaskannya di seluruh jaringan tubuh yang membutuhkan, kemudian mengikat CO2 dari jaringan tubuh dan melepaskannya di paru-paru (Poltekkes Depkes, 2010).

Menurut Soebroto (2009), anemia adalah penyakit kurang darah yang ditandai dengan kadar hemoglobin $(\mathrm{Hb})$ dan sel darah merah (eritrosit) lebih rendah dibandingkan normal. Kadar hemoglobin kurang dari $14 \mathrm{~g} / \mathrm{dl}$ dan eritrosit kurang dari $41 \%$ pada pria, maka pria tersebut dikatakan anemia. Demikian pula pada wanita, wanita yang memiliki kadar hemoglobin kurang dari $12 \mathrm{~g} / \mathrm{dl}$ dan eritrosit kurang dari $37 \%$, maka wanita itu dikatakan anemia. Anemia adalah kondisi medis dimana jumlah sel darah merah atau hemoglobin kurang dari normal.Hemoglobin normal pada pria adalah 14-18 gr \%, sedangkan pada wanita hemoglobin normal adalah 12-16 gr \% (Poltekkes Depkes, 2010).

Menurut WHO (2000), derajat anemia ditentukan oleh kadar HB, klasifikasi derajat anemia yang dipakai adalah:

a. Ringan, $\mathrm{Hb} 10 \mathrm{gr} / \mathrm{dl}-12 \mathrm{gr} / \mathrm{dl}$

b. Sedang, $\mathrm{Hb} 8 \mathrm{gr} / \mathrm{dl}-9,9 \mathrm{gr} / \mathrm{dl}$

c. Berat, $\mathrm{Hb}<8 \mathrm{gr} / \mathrm{dl}$

Untuk pencegahan penyakit anemia sebenarnya sangat mudah seperti dengan mengkonsumsi makanan-makanan yang banyak mengandung zat besi, asam folat, vitamin B12, vitamin C 


\section{Metode Penelitian}

Penelitian ini menggunakan pendekatan fenomenologi yaitu peneliti dengan cara menangkap dan menggali fenomena atau gejala yang timbul dari objek yang diteliti). Jenis penelitian yang digunakan adalah penelitian kualitatif. Desain penelitian yang digunakan fenomologis, Pada penelitian ini peneliti menggali persepsi mahasiswa DIII kebidanan tentang pencegahan anemia di Stikes Karya Husada Semarang. Pengambilan sampel dalam penelitian ini menggunakan teknik purposive sampling. Instrumen penelitian yang akan digunakan dalam penelitian ini antara lain: Peneliti sendiri, Pedoman Wawancara, Alat Perekam, Buku Catatan dan Alat Tulis. Data kualitatif yang didapat diolah dengan cara sebagai berikut: Memahami informasi, Menyusun daftar untuk partisipan, Melakukan pengkodean, Mengelompokkan kedalam kategori - kategori, Membuat keputusan akhir Mengumpulkan setiap materi yang ada dalam satu tempat dan memulai melakukan analisis awal. Proses kredibilitas data diperoleh melalui metode uji coba wawancara pada subyek yang memiliki karakteristik yang sama. penelitian ini dilaksanakan pada bulan Januari 2016, di bertempat di Asrama Prodi DIII Bidan Stikes Karya Husada

\section{Hasil Penelitian}

\section{A. Mengeksplorasi persepsi mahasiswa D III Kebidanan tentang pencegahan anemia} di STIKES Karya Husada Semarang Semarang.

1. Apakah sudah pernah mendengar tentang Anemia

“...ehm....kalau setau saya” (P1)

“...ehmm....pernah dengar sih mba ....” (P2)

“...tahu mba....cuma pernah dengar ...” (P3)

2. Pengetahuan tentang Anemia

“...ehmm....pernah dengar sih mba, setauku anemia itu menurut saya kalau gak salah kurang darah mba...” (P.1)

"...ehmm....kalau setau saya anemia itu ya mba kurang darah itu loh mba ..." (P2)

3. Asal mengetahui tentang Anemia

“...kalau saya tahunya dari internet, terus pernah dengar mba (P.1)

“...emm...itu mba saya tahu dari internet mba.. (P.2) 
4. Apakah mengetahui tanda dan gejala anemia

“... oh..itu mba... ehmm, kalau gak salah itu ada tanda-tandanya ya mbak 5L itu loh mbak lesu, letih, lunglai, lemes kurang konsentrasi rasanya juga sering pusing-pusing mba..." (P.1)

“... yaa...pernah baca ya mba kalau tentang tanda-tanda anemia itu, lemas, lesu, letih, sering pusing mba, saya tahunya itu mba, tanda-tanda anemia” (P.2)

“....setau saya kalau tanda anemia itu pusing, lemah, wajahnya pucat, matanya sering berkunang-kunang rasanya kalau anemia gitu mba...(P3)

5. Apakah yang sudah dilakukan untuk pencegahan anemia “.......saya mba biasanya makannya teratur, terus kalau itu mba istirahat kalau kepala saya pusing-pusing mba, saya buat istirahat udah gak pusing mba...” (P.2) “....saya pernah merasakan seperti sulit konsentrasi dikelas, rasanya pusing mba, kalau makannya jarang tapi lama-lama teratur mba...(P.3)

6. Upaya yang dilakukan jika sudah anemia

“... paling kalau saya itu mba istirahatnya cukup terus minum vitamin sama obat tambah darah tablet Fe mba...” (P.1)

“... saya kalau sudah terjadi anemia yaa...paling saya istirahat cukup kemudian makan-makanan bergizi seperti sayuran, buah dan saya beli obat tambah darah mba..." (P.2)

“....kalau saya sudah tau anemia itu mba...saya istirahatnya lebih sering mba, terus beli obat tambah darah biar mengurangi pusing mba.,terus kalau makannya teratur.." (P.3)

7. Apakah usaha yang sudah dilakukan sesuai dengan teori pencegahan anemia “......kalau saya sudah sesuai dengan teori sama persis ya paling makannya teratur pake sayur mba, trus minum es jeruk atau gak mba beli vitamin” (P.1) “.... itu mba biasanya saya beli vitamin, terus makannya pake sayuran, kacangkacangan kadang-kadang daging mba.” (P.3)

Berdasarkan hasil penelitian didapatkan bahwa semua partisipan dan sudah pernah mendengar tentang Anemia. Dan didapatkan juga bahwa semua partisipan sudah mengetahui tentang persepsi pencegahan Anemia. Hal ini dilihat dari pendapat partisipan 1 dan 2 mengatakan Anemia adalah kurang darah, sedangkan Partisipan 3 mengatakan bahwa adalah darah kurang dari normal. Pengetahuan tentang anemia 2 dari 3 partisipan yaitu partisipan 1 dan 2 mengatakan mendapat informasi tentang Anemia dari internet. Sedangkan partisipan 3 mengatakan bahwa mendapat informasi anemia adalah pernah mendengar. Hal ini tidak sesuai dengan pernyataan triangulasi yang mengatakan tidak pernah memberi informasi tentang anemia pada saat kegiatan mahasiswa diasrama pada waktu berkumpul.

Menurut Soebroto (2009) Anemia adalah kurang darah yang di tandai dengan kadar hemoglobin $(\mathrm{Hb})$ dan sel darah merah (eritrosit) lebih rendah dibandingkan normal. Kadar 
hemoglobin kurang dari $14 \mathrm{~g} / \mathrm{dl}$ dan eritrosit kurang dari $41 \%$ pada pria, maka pria tersebut dikatakan anemia.

Demikian pula wanita, wanita yang memiliki kadar hemoglobin kurang dari $12 \mathrm{~g} / \mathrm{dl}$ dan eritrosit kurang dari 37\%, maka wanita itu dikatakan anemia.

Dalam penelitian ini dapat dianalisa bahwa anemia merupakan. Keadaan dimana mengalami kurang darah dari normal. Dan bahwa semua partisipan sudah mengetahui persepsi tentang pencegahan anemia.

Berdasarkan hasil penelitian didapatkan bahwa semua partisipan sudah mengetahui tentang tanda dan gejala Anemia. Dan didapatkan juga bahwa semua partisipan sudah mengetahui tentang tanda dan gejala anemia. Hal ini dilihat dari pendapat partisipan 1 dan 2 mengatakan tanda dan gejala anemia adalah 5 L lesu,letih, lunglai, lemes, kuramg konsentrasi rasanya juga sering pusing, sedangkan Partisipan 3 mengatakan bahwa adalah merasakan seperti sulit konsentrasi dikelas. Hal ini tidak sesuai dengan pernyataan triangulasi yang mengatakan tidak pernah memberi informasi tentang tanda dan gejala anemia pada saat kegiatan mahasiswa diasrama. Partisipan 1,2,3 mengatakan bahwa mendapatkan informasi tentang tentang danda dan gejala anemia dari internet, dan membaca.

Menurut Saifuddin (2006) tanda dan gejala anemia diantaranya adalah keluhan lemah, pucat, mudah pingsan sementara tensi dalam batas normal, perlu dicurigai anemia defisiensi besi. Secara klinis dapat dilihat tubuh yang malnutrisi pucat.

Dalam penelitian ini dapat dianalisa bahwa partisipan 1,2,3 sudah mengetahui tanda dan gejala anemia yang di ungkapkan partisipan 1 bahwa $5 \mathrm{~L}$ lesu, letih, lunglai, lemes, kuramg konsentrasi rasanya juga sering pusing, Partisipan 2 mengatakan lemas, lesu, letih, sering pusing dan partisipan 3 mengungkapkan merasakan seperti sulit konsentrasi dikelas. Hal ini di dapatkan dari internet dan pernah membaca materi tentang tanda dan gejala anemia, dimana hal ini sesuai pada triangulasi mengungkapkan bahwa belum pernah memberikan informasi terkait penkes tentang anemia di asrama

Menurut Soebroto (2009) tanda dan gejala anemia adalah gejala yang sering muncul pada penderita anemia diantaranya lemas, letih, lesu, mudah lelah, dan lunglai, wajah pucat, mata berkunang-kunang, nafsu makan berkurang, sulit konsentrasi dan mudah lupa.

Menurut penelitian sebelumnya oleh melani puji astuti, puput lestari dan agustin setyowati adalah tanda dan gejala anemia adalah gejala yang sering muncul pada penderita anemia diantaranya lemas, letih, lesu, mudah lelah, dan lunglai. 
Berdasarkan hasil penelitian didapatkan bahwa semua partisipan sudah cara melakukan pencegahan tentang anemia. Dan didapatkan juga bahwa semua partisipan sudah mengetahui cara melakukan pencegahan anemia. Hal ini dilihat dari pendapat partisipan 1 dan 2 mengatakan cara melakukan pencegahan anemia adalah istirahat cukup kemudian nimum vitamin juga obat tambah darah, sedangkan Partisipan 3 mengatakan bahwa adalah istirahatnya lebih sering kemudian beli obat tambah darah. Pengetahuan tentang pencegahan anemia 2 dari 3 partisipan yaitu partisipan 1 dan 2 mengatakan cara melalukan pencegahan anemia yang sudah sering dilakukan adalah mengkonsumsi makanan yang bergizi seperti sayur-sayuran yang berwarna hijau, kacang-kacangan, ikan, daging, buah-buahan serta mengkonsumsi vitamin. Sedangkan partisipan 3 mengatakan bahwa cara melakukan pencegahan anemia adalah mengkonsumsi makanan teratur dan bergizi seperti sayuran, kacang-kacangan, ikan kadang buah mengkonsumsi vitamin dan tablet tambah darah. Hal ini sesuai dengan pernyataan triangulasi yang mengatakan motivasi untuk makanan sehat dalam upaya cara melalukan pencegahan anemia. Dimana partisipan melakukan pencegahan anemia sesuai dengan kemampuan ekonomi dan gaya hidup yang biasa dilakukan dilingkungan asrama.

Menurut Soebroto (2009) cara melakukan pencegahan anemia adalah dengan mengkonsumsi makanan-makanan yang banyak mengandung zat besi, asam folat, vitamin B12, vitamin C. Berikut jenis makanan yang membantu mencegah terjadinya anemia dengan seperti sayuran hijau, buah-buahan dan lain-lain.

Dalam penelitian ini dapat dianalisa data bahwa melakukan pencegahan anemia dapat dilakukan dengan mengkonsumsi makanan yang banyak mengandung sayur-sayuran, kacangkacangan, buah-buahan. Pada sebagian ada yang mengkomsumsi obat tambah darah.

Menurut Depkes (2010) pencegahan anemia seperti dengan mengkonsumsi makananmakanan yang banyak mengandung zat besi,seperti daging, kacang, sayur-sayuran dan lainlain. Asam folat seperti sayuran hijau, jenis kacang-kacangan, jeruk dan lain-lain. Vitamin B12 bisa didapatkan dengan mengkonsumsi daging dan susu. Vitamin C dapat diperoleh dari buah jeruk.

Menurut penelitian sebelumnya oleh melani puji astuti, puput lestari dan agustin setyowati pencegahan anemia sering dilakukan dengan mengkonsumsi makanan bergizi, seperti sayuran, buah-buahan, vitamin .

\section{Kesimpulan}


Berdasarkan teori, hasil penelitian dan pembahasan yang telah peneliti lakukan maka dapat ditarik kesimpulan sebagai berikut:

1. Persepsi mahasiswa D III Kebidanan Tentang anemia Anemia pada remaja dapat berdampak pada menurunnya produktivitas kerja atau pun kemampuan akademis di sekolah, Karena tidak adanya gairah belajar dan konsentrasi terutama pada anak sekolah atau mahasiswa antara lain adalah kesakitan, dan kematian meningkat pertumbuhan fisik, perkembangan otak, motorik, mental dan kecerdasan terhambat daya tangkap belajar menurun, pertumbuhan dan kesegaran fisik menurun. Masih adanya beberapa remaja yang belum mengetahui tentang bagaimana cara pencegahan anemia dengan benar, tetapi ada juga yang sudah mengetahui cara pencegahanya dengan baik dan benar.

2. Persepsi mahasiswa D III Kebidanan tentang tanda dan gejala anemia di STIKES Karya Husada Semarang yang sering dirasakan yaitu 5 L ( letih, lemah, lunglai, lesu, sering pusing). Gejala-gejala yang disebabkan oleh pasokan oksigen yang tidak mencukupi kebutuhan ini bervariasi. Anemia biasa menyebabkan kelelahan, kelemahan, kurang tenaga, dan kepala terasa melayang. Jika anemia bertambah berat, dan diharapkan dapat mengatasi jika mengalami tanda dan gejala anemia tersebut

3. Persepsi mahasiswa D III Kebidanan tentang cara pencegahan anemia di STIKES Karya Husada Semarang adalah dengan sering mengkomsumsi makanan bergizi seperti sayuran yang berwarna hijau, buah-buahan, kacang-kacangan, ikan, daging dan mengkonsumsi vitamin dan obat tambah darah.

\section{Saran}

Mahasiswa lebih meningkatkan cara-cara mencegah anemia seperti diet dengan menu gizi seimbang, contohnya sayuran,buah-buaha, daging, ikan yang cukup sehingga mahasiswa dapat terpenuhi asupan gizi dengan baik dan benar. Dan bagi ibu asrama dapat memberikan pendidikan kesehatan tentang pencegahan anemia pada mahasiswa D III Kebidanan, juga motivasi tentang makanan sehat sehingga dapat memantau keadaan mahasiswa serta dapat melakukan upaya pencegahan anemia yang dialami mahasiswanya.

\section{Daftar Referensi}


Arikunto, Suharsimi.2010" Prosedur Penelitian Suatu Pendekatan Praktik Jakarta : Rineka Cipta

Azwar, Saifuddin. 2013 “Pengantar Psikologi Intelegensi” Yogyakarta : Pustaka Pelajar

Bambang T..,2007. Anemia defisiensi Besi pada Anak Sekolah: hppt://suara merdeka.com

Chatarina,U. W..,Notobroto, H, B.,2002. Peranan Pola Makan Terhadap Anemia Gizi pada Remaja_Putri Pondok Pesantren di Surabaya Tesis, Universitas Diponegoro, Surabaya.

DKK Kab. Brebes,2006. Hasil Pemeriksaan Kadar Hemoglobin Pada Remaja Putri/WUS, Brebes

Elly, H, 2001. Prevalensi Anemia dan Perilaku Makan Remaja Putri di SMUN 2 Kuningan Kabupaten Kuningan, Skripsi, Universitas Diponegoro,Semarang

Hamalik, Oemar. 2012 “Psikologi Belajar Dan Mengajar” Bandung : Sinar Baru Algesindo

Kusumandari, W. (2010).Bidan sebuah pendekatan midwifery of knowledge. Yogyakarta: Nuha Medika.

Moelong, lexy, 2004.” Metodologi Penelitian" Bandung : PT Remaja Rosdakarya

2007. "Metodologi Penelitian kualitatif edisi revisi” Bandung : PT Remaja Rosdakarya

Mukhtar dan Iskandar. 2012. “ Desain Pembelajaran Berbasis TIK” Jakarta: Referensi

Notoadmodjo, 2010.” Metode Penelitian Kesehatan “ Jakarta : Rineka Cipta

Nursalam. (2008). Konsep dan penerapan metodologi penelitian ilmu keperawatan : pedoman skripsi, tesis dan instrument penelitian keperawatan. Jakarta : salemba medika

Pieter, zan, herri. 2010. “Pengantar Psikologi Dalam Keperawatan” Jakarta : Prenada Media Group

Prawirohardjo, S. (2006).Buku acuan nasional pelayanan kesehatan maternal. Jakarta: Yayasan Bina Pustaka Sarwono Prawirohardjo.

Saryono, 2013. Metodologi Penelitian Kualitatif Dan Kuantitatif' Yogyakarta: Nuha Medika Sugiyono. (2008). Metode penelitian pendidikan (pendekatan kuantitatif, kualitatif, dan $r \& d$ ). Bandung: Alfabeta. 